\title{
Median Or Lower Cervical Lymph Node
}

National Cancer Institute

\section{Source}

National Cancer Institute. Median Or Lower Cervical Lymph Node. NCI Thesaurus. Code C103417.

A lymph node located in the median or lower region of the neck. $(\mathrm{NCl})$ 